- Sawyer, Donald; Myanna Lahsen. 2016. "Civil Society and Environmental Change in Brazil's Cerrado." Environment: Science and Policy for Sustainable Development Nov.-Dec., 11 Oct (Online). Doi: 10.1080/00139157.2016.1229541.

\title{
CIVIL SOCIETY AND ENVIRONMENTAL CHANGE IN BRAZIL'S CERRADO
}

\author{
Donald Sawyer ${ }^{1}$ and Myanna Lahsen ${ }^{2}$
}

\begin{abstract}
Based on previous experience, literature review, interviews and consultations, this study describes and analyzes the context of key civil society organizations (CSOs) addressing environmental and social sustainability in the Cerrado savannas of central Brazil. This analysis considers CSOs at all scales (international, national, sub-national and local). It reveals the vital roles played by a host of actors in identifying the threats to people and ecosystems in the Cerrado. It concludes with recommendations as how to improve their capacity and impact, including by making adjustments in adverse legal frameworks, reducing knowledge gaps, drawing CSOs and donors more directly into the Cerrado, and generally establishing greater awareness and synergy between environmental and social resilience.
\end{abstract}

\section{Introduction}

Representing a plurality of knowledges, values and initiatives, civil society organizations can be a central force behind progressive transformations, creating the necessary pressure to effect changes in other sectors, not least governments and private sector parties [1]. This study describes and analyzes the context of civil society organizations, including their actual or potential roles in conservation and sustainable development in the Cerrado savannas of central Brazil, the challenges they face, and actions that could enhance their participation in decision making important for the region. ${ }^{3}$ The study is based on

\footnotetext{
${ }^{1}$ Senior Advisor, Instituto Sociedade, População e Natureza (ISPN). Instituto Sociedade, População e Natureza - ISPN. SHCGN CLR, Quadra 709, Bloco E, Loja 38. 70.750-515 Brasília DF, Brasil.instituto@ispn.org.br, www.ispn.org.br. The viewpoints, errors and omissions are the sole responsibility of the authors.

${ }^{2}$ Senior Associate Researcher, Center for Earth System Science, Brazilian Insitute for Space Research (INPE), São José dos Campos, São Paulo, Brazil. E-mail: myannal@gmail.com ${ }^{3}$ For a detailed list of the names and types of CSOs operating in the Cerrado or otherwise relevant to activities in it, please see chapter 8 of Sawyer et al. 2016.
} 
Sawyer's extensive personal and institutional experience since 1990, literature review, together with interviews and stakeholder consultations carried out as part of the Ecosystem Profile of the Cerrado Biodiversity Hotspot [2] for the Critical Ecosystem Partnership Fund (CEPF). The objective is to convey the complex and atypical social characteristics and conditions of CSOs and to formulate recommendations for civil society itself as well as for government and donors. The premise is that CSO interventions and participation in decision making processes are vital to the future of this poorly understood biome which is of vital economic and environmental importance to the Brazil and surrounding countries.

Civil society organizations (CSOs) are defined as all the international, national, subnational and local non-government actors that are relevant to environmental sustainability. In Brazil, social movements such as indigenous organizations, labor unions (especially of rural workers, including family farmers) and professional and religious organizations are not primarily environmental, but they are nonetheless important to overall environmental safeguard. ${ }^{4}$

\section{Civil Society Organizations in Brazil}

Before democracy was re-established in Brazil in 1985, organizations mediating between citizens and governments were rare [3]. Since then, they have multiplied and spread from the Southeast and South to the North, Northeast and Center-West regions. A mapping of active private foundations and non-profit associations in 2012 [4] identified 290,700 foundations and associations in Brazil. Of these, 2,242 organizations (0.8\%) were specifically dedicated to environment and animal protection in Brazil, a small percentage but still a significant number in absolute terms. 14.6\% focused on development and advocacy. The main foci of national CSOs were religion (28.5\%), employers and professional associations (15.5\%), and health, education, research, and social assistance related to government policies $(18.6 \%)$.

Although the proportion of CSOs dedicated specifically to the environment is small, all the other organizations deal with the wellbeing of people and environment in one way or another. They contribute to decisions affecting the environment through their participation in councils, commissions and conferences of various kinds. They also affect environment through their influence on private and public behavior, although local environmental CSOs can only achieve broad objectives through working together with the rest of society.

The National Environment Council (CONAMA) maintains a National Registry of Environmental Organizations (CNEA) with contact information for each organization that applies and includes environment in its bylaws. The Center-West region, most representative of the Cerrado, has 74 member organizations. The Northeast has 123, the Southeast 283, the South 125 and the North 44, for a total of 649 in Brazil; 28.9\% of the 2,242 environmental

\footnotetext{
${ }^{4}$ Women's organizations are also relevant but not included here because they generally are more concerned with gender equality, domestic violence and reproductive and sexual health and rights and have resisted taking on the additional burden of defending the environment (Sawyer 1997).
} 
organizations in the FASFIL survey. Of the 649 organizations registered in CNEA in Brazil, the Center-West has only $11.4 \%$, behind only the North, as is also the case in FASFIL.

Despite their efforts, civil society associations and networks face difficulties keeping their organizations afoot and influencing public policy. Since there are many more social CSOs than environmental CSOs, and the large national and international environmental CSOs are most active in other biomes, there is a shortage of CSOs dedicated primarily to the environmental protection, particularly in the Cerrado.

At the same time, however, as with governments, many social movements have undergone a "greening" process, becoming more concerned about environmental issues [5]. In the opposite direction, shifting from a more environmental to more social emphasis, some conservationist movements have added more pronounced social concerns, generating labels of them as 'socio-environmental' or 'eco-social' organizations and movements.

Experience shows that projects on the environment can spur social movements to put "green" issues onto their own respective agendas, without having to create and maintain strictly environmental CSOs. Enabling existent CSOs to incorporate environmental dimensions might be the best approach for the Cerrado. It would be unrealistic to create strictly environmental organizations in this region given bureaucratic barriers, and challenging high costs and funding limitations.

\section{Operating Conditions for CSOs}

There are serious difficulties with the legal framework for civil associations in Brazil, especially for local organizations outside the capital cities and close to nature. There is no legal status for NGOs, with that terminology, although the acronym ('ONG' in Portuguese) is in common use. They are now classified as CSOs. In order to have legal standing, nonprofit associations must have bylaws, annual assemblies, elected officers, fiscal councils and accountants, among other requirements.

It is very difficult to comply with official rules and regulations regarding receipt and expenditure of government funds, which require bidding, complex accounting and reporting. Various agencies monitor and enforce regulations, such as the Federal Accounts Court (TCU). Non-compliance requires returning all the funds with interest and monetary correction for inflation, even after many years. Any civil association in Brazil must obey the labor legislation, which requires 30 days of paid vacation, a 13th month wage, maternity leave, payment of social security and payment into a severance fund, among other payroll expenses.

The government has created Social Organizations (OS) and Public Interest Civil Society Organizations (OSCIPs) to facilitate operations in some cases. Such organizations are rare, and face major difficulties. A new legal framework for civil society organizations is being debated, and a congressional bloc to defend CSOs has been created, but many of the 
shortcomings remain in the legislative drafts being considered. A new statutory framework would certainly help, even if it does not solve all the problems.

Obtaining needed financial support is a big challenge for CSOs. Philanthropy within Brazil is historically weak, with few signs of improvement [6]. The prevailing assumption is that government is responsible for everything. Moreover, nonprofit organizations are not eligible for bank credit. Cooperatives for small farmers can get bank credit, but have difficulty in complying with complex bureaucratic requirements and finding reliable leaders. 'Social enterprises' such as FrutaSã, in Carolina, Maranhão, owned by the Vyty-Cate indigenous association, are non-profit private companies. This form of organization manages to solve problems such as access to credit, but is still very rare.

There is much radicalization and polarization in CSO actions; seeking compromise is still rare. Confronting powerful interests is a dangerous business. Socio-environmental conflicts are widespread [7]. Of 11,338 rural conflicts surveyed by the CPT between 2005 and 2014, 39\% were in the Cerrado [8]. Environmentalists, rural workers and indigenous leaders are regularly being murdered in the interior of Brazil [9]: Chico Mendes is not alone.

\section{Civil Society Activities in the Cerrado}

The Cerrado Network, a legacy of the "Cerrados Treaty" signed by NGOs at the Rio Conference in 1992, involves hundreds of local civil society organizations. It organizes biannual national meetings and fairs of Cerrado peoples. Because of lack of funding for the Cerrado, its office is now closed, with no staff of its own. It operates through its member organizations.

The Cerrado Central Cooperative (Central do Cerrado), based in Brasília, is a second-order cooperative joining 30 cooperatives from all over the Cerrado to market a wide range of sustainable-use biodiversity products. It ensures high visibility for these products in the national capital and in the Pinheiros municipal market in São Paulo.

The Pacari Network works with medicinal plants at the community level in the Cerrado, primarily in Goiás and Minas Gerais, and has begun to develop cosmetics for formal markets because of the difficulties of compliance with rigorous regulations for health products. It won the UNDP Equator Prize, which champions environmental and social achievements of rural CSOs, in 2012.

The Mobilization of Indigenous Peoples of the Cerrado (MOPIC), created in 2008, is a network that seeks to unite indigenous groups in approximately 100 Indigenous Lands throughout the Cerrado. Previously, Cerrado indigenous groups were a minor part of larger organizations in Brazil or the Amazon basin. MOPIC is part of the Cerrado Network. VytyCate, in Maranhão and Tocantins, the Kanindé Ethno-Environmental Defense Fund, in Rondônia, and Warã, in Mato Grosso, are examples of local indigenous (or indigenist) associations. 
WWF carries out the tri-national Cerrado-Pantanal project in the entire Upper Paraguay River basin, including Mato Grosso do Sul, Mato Grosso, Bolivia and Paraguay. The focus is on freshwater ecosystem conservation, protected areas, sustainable value chains and territorial planning, including all three countries. WWF also works with the Sertão Veredas-Peruaçu Protected Areas Mosaic in northern Minas Gerais.

The Nature Conservancy (TNC) helps rural landowners comply with the Forest Law in western Bahia and northern Mato Grosso, in close association with agribusiness, including the Bunge Corporation. It also works closely with indigenous groups, mostly in the Amazon region.

Conservation International has a long history of experience in the Cerrado. In 1997, it initiated actions to protect the Emas National Park in Goiás, creating both the EmasTaquari Corridor and later the Cerrado-Pantanal Corridor. It was also responsible for coordinating the preparation of the first version of the document 'Priority Actions for the Conservation of the Cerrado and Pantanal Biodiversity' in 1998. In 2001, it played a crucial role in creating the Jalapão Ecological Station in Tocantins, one of the largest protected areas in the Cerrado, with 716,000 hectares. More recently, between 2010 and 2014, it carried out, in partnership with Monsanto, the Produce and Conserve Program, focusing on restoration of Permanent Preservation Areas and strengthening of seed collector networks in western Bahia, part of the region called "Matopiba". Currently, as a GEF Implementing Agency, it is preparing a proposal in partnership with the Federal Government, the Brazilian Rural Society (SRB) and the Brazilian Foundation for Sustainable Development (FBDS) to promote the protection of natural capital and zero net deforestation in Matopiba, including actions for restoration and compliance with the Forest Law.

The Socioenvironmental Institute (ISA) is a large Brazilian NGO based in Brasília. Its work in the Cerrado is carried out in the transition to the Cerrado in the southern part of the Xingu Indigenous Park and in northeastern Mato Grosso, where it promotes compliance with the Forest Law through planting of native seeds and seedlings. It plays a key role in national networks and in policy dialogue.

The Institute for Society, Population and Nature (ISPN), headquartered in Brasília and with a branch office in Maranhão, is one of the middle-size Brazilian NGOs that work mostly in the Cerrado. Founded in 1990, it has participated in work on conservation and biodiversity (priority areas and actions, conservation law). It once provided the secretariat of FBOMS, and is now responsible for the administrative coordination of the Cerrado Network. Since 1995, it has managed the GEF-UNDP Small Grants Program, supporting 380 projects carried out by 275 local or regional organizations all over the Cerrado, as well as organizations in the Caatinga, in the Northeast, and the Arch of Deforestation, the transition between the Cerrado and the Amazon. The National Steering Committee selects projects from a pool of applicants that is seven times greater than the number that can be supported.

Brazilian social movements active in the Cerrado include the National Confederation of Agricultural Workers (CONTAG), the National Federation of Men and Women Workers in Family Farming (FETRAF), the Pastoral Land Commission (CPT), the Landless Workers' Movement (MST), the Small Farmers' Movement (MPA) and the Rural Workers' Movement 
(MTC), among others. The CPT, with headquarters in Goiânia, Goiás, has launched a specific campaign to defend the Cerrado. These social movements are all increasingly concerned with the environment, in part because of their own needs and interests and in part because the environment is a way for them to criticize big business. Experience shows that projects on the environment can spur social movements to put "green" issues on their own respective agendas, without attempting to create and maintain strictly environmental CSOs, which would be an unrealistic undertaking in the Cerrado, given bureaucratic barriers, high costs and reductions in funding.

\section{Civil Society Capacity in the Cerrado}

Development forces have left the "socioenvironmental" movement in Brazil with little power [10]. There is little coordination and joint efforts between civil society and priviate initiatives, and it is very difficult for CSOs to comply with unrealistic government regulations, which do not pay for administrative expenses and require complex bidding and financial reporting, among many other bureaucratic difficulties intended to avoid corruption. Use of internet is mandatory. There is also limited knowledge in civil society about the complex legal frameworks and government policies and programs relevant to the environment. There are regional variations, with the strongest organizations in the national and state capitals and limitations in the interior.

In the Cerrado, civil society capacity is highest in the states of São Paulo and Minas Gerais, including the interior. It is also high in the Federal District, Brazil's national capital, although most of the organizations located there operate at a larger scale, reaching other states. Even the organizations with the highest capacity need institutional strengthening, as was made clear in the consultation workshop with civil society. One of those needs regards implementation of the new Regulatory Framework for Civil Society Organizations (MROSC).

The private sector is well organized in the Cerrado in sectoral associations such as APROSOJA and ABIOVE. It has also participated in the Round Table on Responsible Soy (RTRS). There is a specific organization for coffee, gourmet varieties of which are now produced in the Cerrado. The Cerrado No-Till Farming Association (APDC) has brought about a remarkable shift in crop management through conservation. There is increasing concern over environmental deterioration because of market pressures and scarcity of water. This is already being felt by coffee growers in Minas Gerais, who may also be pushed south by the effects of climate change. The private sector in the Amazon region has previous experience with the Soy Moratorium, Brazilian government supported boycott of soy from recently cleared areas. However, since this applies only to the Amazon and excludes the Cerrado, it could cause further leakage to the south. There should be the same moratorium on purchases of soy or beef from recently cleared areas in the Cerrado.

\section{$5 \quad$ Addressing Gaps in Civil Society Capacity}


The civil society consultation workshop held during the ecosystem profile process, together with various other stakeholder consultations, confirmed previous observations that there is strong need for:

1. Small grants that could be made available in all areas in which the applicants can demonstrate strategic relevance. For local organizations, it is essential to simplify the bureaucratic requirements. When this is not possible, subcontracting by larger organizations can be an alternative. Small grants can influence the work of large-scale social movements so as to include the environment.

2. Consolidation grants, for larger amounts and longer periods, that would be important for organizations that have demonstrated capacity to generate relevant impacts and that face high operating expenses in order to maintain offices and qualified staff in capital cities as well as working in remote locations in the interior.

3. Continuous institutional support essential for maintaining networks among CSOs of various kinds (regional, thematic, indigenous) so that they can maintain offices and staff over time, not just for specific short-term projects, and hold regular meetings involving members who must travel long distances.

4. Capacity development that is needed for CSO representatives in order to ensure qualified participation in official councils, commissions and conferences. There are many such bodies and consultations for the environment, rural development, citizenship territories, traditional peoples and communities, and watersheds, among others, but the representatives need to know more about complex legal frameworks, organizations and programs, past history, future prospects and 'who's who' among relevant players.

5. Specific capacity development for community leaders who, in order to represent civil society at the ecosystem level and defend collective causes that are for the common good, need to become familiar with other groups and other parts of the Cerrado.

6. Specific capacities for indigenous representatives who need to enhance their perpetual participation in national and international forums and negotiations. Indigenous issues are not limited to Brazil, and being confined to Portuguese is of little or no use for contacts and participation in meetings in other countries.

7. Further guidance to journalists in various kinds of media, who have little knowledge about the Cerrado or the best ways to achieve appropriate conservation outcomes.

Until changes are made in the legal framework, one way to overcome barriers to local civil society organizations is for them to work together with larger organizations in capital cities that are better prepared to deal with all the official regulations and that can subcontract the local organizations in the interior. Thus, local communities would not need to carry out 
bidding processes and document every expense in ways that are not available or feasible in remote rural areas of the Cerrado.

\section{Conclusions}

More than ever before, even when Rio-92, Rio+5 and Rio+20 were held in Brazil, multinational environmental agreements are exerting increasing influence on domestic civil society, especially as regards climate change, for which CSOs have organized networks and participated in international events. The Sustainable Development Goals are becoming a reference arena for some CSOs. Globalization of environmental governance is increasingly influencing government and society within Brazil, whose thinking has tended to be relatively isolated from environmental concerns [11].

Although only a few environmentalist CSOs are already active in the Cerrado, important national-level organizations of various kinds can be attracted to the biome and incorporate specific environmental concerns into their own agendas. There are also at least a hundred local organizations, though not primarily environmental, are already involved in environmental issues. Beyond them, there are thousands of formal and informal labor, church, civic, business, academic and indigenous organizations that are increasingly concerned about the environment, but which need stimulus and support to be fully effective. This is especially true in the northern part of the Cerrado.

The main barriers to the survival and effectiveness of Brazilian CSOs in promoting outcomes that are environmentally, socially and economically sustainable include:

1. Complex and unrealistic regulations regarding nonprofit organizations, government contracts, the need to comply with labor laws, requirements limiting the use of government funds etc. [12];

2. Expectations that the State is ubiquitous and omnipotent and capable of registering, mapping, licensing, monitoring and controlling private activities, even in large remote areas [13].

3. Lack of solid technical, empirical and quantified [14] understanding of basic issues such as urban and rural heat islands, aerial rivers, watershed integrity, ecosystem functions and regional economics.

4. Lack of civil society representatives with sufficient technical and administrative knowledge to participate effectively in official councils, commissions and consultations;

5. Political polarization and lack of realistic environmentalist proposals that are economically feasible, without benefiting specific private interests [14];

6. Excessive biocentrism and anthropocentrism, at the two extremes, with limited socio-environmental, eco-social or multi-sectoral integration [15]. 
Based on analysis of past experiences and recent consultations [16], key opportunities to improve civil society performance can be summarized as follows:

1. Stress the interdependence of aquatic, biodiversity and climate dimensions of environment ("ABC") and the need to reconcile society and environment, living in harmony with nature;

2. Encourage the 'greening' of CSOs that are not primarily concerned about environment;

3. Strengthen the institutional capacity of existing CSOs, and forge vertical and horizontal partnerships among large and small CSOs.

4. Facilitate more effective representation in government processes by providing information and means;

5. Work with all three branches of government at all three levels (federal, state and municipal);

6. Insist on the reduction of domestic non-tariff barriers that make sustainable use of biodiversity practically impossible [17];

7. Base all development proposals on scientific and technical analyses that include quantification of effects, costs and benefits.

8. Raise greater awareness about the Cerrado itself and about savannas in all of Brazil and abroad, so that the Cerrado is part of a broader category that also exists outside Brazil;

9. Effectively apply the private sector's declared commitment to sustainability and avoid greenwashing;

10. Integrate networks on inter-municipal, state, regional, inter-regional and international scales.

Analysts concur $[2,10]$ : To be effective, civil society groups working for the larger good in the Cerrado and in Brazil more generally need to rethink and strengthen the structure and capacity of their movement, which will require transformation of their political cultures and of their ability to strategize. To convince others that they are working for the common good rather than their own parochial interests, they need to improve their efforts to communicate externally with other groups, not only internally in the Cerrado or in Brazil but also internationally. This will require learning to communicate in English such that they might effectively attend and make interventions at meetings in both national and international contexts and thereby gain attention, allies, and influence on public opinion and decisionmaking. It will also require a new level of integration with scientists and experts of all kinds, including public relations agents. 


\section{REFERENCES}

1. Scoones, I., M. Leach, and P. Newell, The politics of green transformations. 2015: Routledge.

2. Sawyer, D.C. Ecosystem profile: Cerrado biodiversity hotpot. 2016; Available from: http://www.cepf.net/ SiteCollectionDocuments/cerrado/CerradoEcosystemProfileEN.pdf.

3. Schmitter, P., Interest conflict and political change in Brazil. 1971, Stanford: Stanford University Press.

4. $\mathrm{ABONG}$, et al., Mapeamento das fundações privadas e associações sem fins lucrativos - FASFIL 2010: principais resultados. 2012, Associação Brasileira de ONGs: Rio de Janeiro.

5. Hochstetler, K. and M.E. Keck, Greening Brazil: environmental activism in state and society. 2007: Duke University Press.

6. Escorsim, S.M., A filantropia no Brasil: entre a caridade e a política de assistência social. Revista espaço acadêmico, 2008(86).

7. Assad, L.T., G. Litre, and E.P.d. Nascimento, A vida por um feixe de lenha: Experimento metodológico de gestão de conflitos socioambientais. 2009, Brasília: IABS.

8. Clark, N., Rede Cerrado questiona governo sobre Plano MATOPIBA. 2015

Comissão Pastoral da Terra: Goiânia.

9. Holmes, O., Environmental activist murders set record as 2015 became deadliest year, in The Guardian. 2016.

10. Weiss, J.S., O papel da sociedade na efetividade da governança ambiental, in Governança Ambiental no Brasil: instituições, atores e políticas públicas, A.M.M.d. Moura, Editor. 2016, Instituto de Pesquisa Econômica Aplicada (IPEA): Brasilia.

11. Viola, E., Globalização, democracia e sustentabilidade: as novas forças sociopolíticas transnacionais, in A geografia política do desenvolvimento sustentável, B.K. Becker and M. Miranda, Editors. 1997, Editora UFRJ: Rio de Janeiro.

12. ECNL, Criação de um marco regulatório para a parceria entre a sociedade civil e as autoridades públicas no Brasil. 2015, European Center for Not-for-Profit Law: Budapest.

13. Flores, M.C., A democracia no Estado onipotente. 2008, Instituto Millenium: Rio de Janeiro.

14. Campanelli, M., Políticas públicas precisam ter base em aspectos técnicos. 2016, São Paulo: Instituto Escolhas.

15. Viola, E. and H. Leis, A evolução das políticas ambientais no Brasil, 1971-1991: Do bissetorialismo preservacionista para o multissetorialismo orientado para o desenvolvimento sustentável, in Dilemas Socioambientais e Desenvolvimento Sustentável. , D. Hogan and P. Vieira, Editors. 1992, Ed. Unicamp: Campinas.

16. Sawyer, D. and A.d.S. Lobo, O papel da sociedade no estabelecimento de políticas públicas para as savanas, in Savanas: desafios e estratégias para o equilibrio entre 
sociedade, agronegócio e recursos naturais, F.G.F.N. Faleiro, Austeclínio Lopes de, Editor. 2008, EMBRAPA Cerrados: Planaltina. p. 1153-1180.

17. Sawyer, D., Entraves regulatórios de atividades extrativistas na Amazônia: problemas, enfrentamentos e soluções, in Soerguimento tecnológico e econômico do extrativismo na Amazônia, T.d.C.B. Pires, Carmem, Editor. 2011, Centro de Gestão e Estudos Estratégicos: Brasília

p. $197-251$. 